\title{
СУБКЛІНІЧНА ГІПОФУНКЦІЯ ЩИТОПОДІБНОЇ ЗАЛОЗИ У ВАГІТНИХ З АУТОІМУНОЛОГІЧНИМ ЗАХВОРЮВАННЯМ ЗАЛОЗИ
}

\author{
ЮЗЕФ КШИСЕК ${ }^{1}$ \\ ТОМАШ МІЛЄВІЧ ${ }^{1}$ \\ САНДРА МРОЗІНСЬКА \\ МАРТА КЯЛКА ${ }^{2}$ \\ АГНЄШКА ОЦЄПКА \\ МАГДАЛЕНА ПУЛЬКА 2 \\ ЄВА СТОХМАЛЬ ${ }^{3}$ \\ МАГДАЛЕНА \\ КШИЧКОВСЬКА- \\ СЕНДРАКОВСЬКА \\ ЗЛАТА ЧАЙКІВСЬКА ${ }^{2}$ \\ ЕЛІНА ЧАЙКІВСЬКА ${ }^{4}$ \\ ${ }^{1}$ Клініка гінекологічної \\ ендокринології Ягеллонського \\ університету, Краків, Польща \\ ${ }^{2}$ Студентське наукове товариство \\ Ягеллонського університету, \\ Краків, Польща \\ ${ }^{3}$ Касредра і клініка ендокринології \\ Ягеллонського університету, \\ Краків, Польща \\ ${ }^{4}$ Касредра акушерства, гінекології \\ та перинатології Львівського \\ державного медичного \\ університету ім. Данила \\ Галицького
}

3 ахворювання щитоподібної залози (ЩЗ) у вагітних зумовлюють розвиток порушень функцій щЗ у плода, а також ускладнюють перебіг гестаційного процесу. Тому серед ендокринологів та гінекологів актуальною є проблема тиреологічного нагляду за вагітною. Важливим аспектом правильного контролю функцій ЩЗ є оцінка концентрації тиреотропного гормона (ТТГ), вільного трийодтироніну (fT3) та вільного тироксину (fT4). При цьому найбільше сумнівів пов'язано з ресеренційними показниками концентрації ТТГ, fТЗ і fТ4 в окремих триместрах вагітності [12, 25].

Низка фрізіологічних процесів, що відбуваються під час вагітності, впливає на обмін гормонів щЗ $[7,9]$. До них належать:

підвищення концентрації білків, що зв'язують гормони щЗ (особливо тироксину та глобуліну, що зв'язує тироксин), у відповідь на підвищення рівня естрогенів вже на ранніх строках вагітності [16];

3 зростання рівня хоріонічного гонадотропіну (ХГ), структурно подібного до тиреотропіну. ХГ, що продукується синцитіотрофобластом, зв'язується з рецептором до ТТГ і набуває власної тиреотропної активності, яка має значення лише у разі високого рівня ХГ. При цьому відбувається супресія виділення ТТГ і підвищення концентрації Т3 і Т4 у сироватці вище ресреренційних показників [14];

5 підвищене виділення йоду із сечею у зв'язку зі збільшенням клубочкової фільтрації під час вагітності.

Очевидно, що й ліки, які може приймати вагітна жінка, значно впливають на фрнкцію ЩЗ.

У таблиці 1 наведено референційні показники (2,5-97,5 перцентиль) ТТГ, fТ3, fТ4 в окремих триместрах вагітності (дані опрацьовані клінікою ендокринології Ягеллонського університету) [28].

Одним із захворювань щЗ, що впливає на розвиток плода та ускладнює перебіг вагітності, є її недостатність. Явна фрорма недостатності спостерігається у 0,3-0,5\% вагітних, а субклінічна - у 2-3\%. Найбільш поширеною причиною недостатності щ3 $€$ ії хронічне аутоімунне запалення - аутоімунний тиреоїдит. Внаслідок порушення функції супресорних Т-лімфоцитів та послаблення імунологічного нагляду системи відбувається надмірна активізація Т-лімфоцитів (Т-хелперів), які стимулюють В-лімфоцити до перетворення у плазматичні клітини. Окрім здатності синтезувати антитіла проти щитоподібних антигенів, плазмоцити можуть стимулювати цитотоксичні лімфоцити, що знищують тиреоцити [4].

Тироксин належить до основних гормонів, які визначають правильний розвиток систем плода, особливо нервової, дихальної та опорно-рухової. Тому надзвичайно важливою $є$ швидка діагностика захворювання та лікування майбутньої матері L-тироксином [15, 18, 23, 24]. На жаль, картина клінічних симптомів у вагітних з недостатністю щз не $є$ характерною $[10,21]$. У разі малосимптомного перебігу захворювання скарги пацієнтки часто приписують вагітності [20]. Лише у разі виражених симптомів недостатності ЩЗ можна швидко діагностувати захворювання. Однак запізніле підтвердження діагнозу може призвести до невідворотних порушень розвитку плода (табл. 2) [4, 17].

Мета нашого дослідження полягала в оцінці частоти появи субклінічної гіпофункції ЩЗ у вагітних з аутоімунним тиреоїдитом.

\section{МАТЕРІАЛ І МЕТОДИ ДОСЛІДЖЕННЯ}

Дослідження проведено серед 282 жінок, які були вагітними в період 2007-2011рр. Пацієнток було рандомізовано на дві групи. До першої групи (А) увійшли 92 вагітні з хронічним аутоімунним запаленням ЩЗ, до другої (В) - 190 вагітних без цього захворювання.

У жінок визначали рівень ТТГ на початку вагітності, в кожному триместрі і перед пологами (всього 5 разів). У зв'язку з тим, що рівень ТТГ коливається протягом доби (максимальна концентрація фріксується вночі, а мінімальна [близько 50\% максимальної] - між 10-ю та 16-ю годинами), кров у пацієнток брали в період між 10-ю та 11-ю годинами. Перед проведенням тесту (щонайменше за 3 дні) жінки вели нормальний спосіб життя: не обмежували себе в їжі і не змінювали своєї дієти та фізичного навантаження, приймали ті ж ліки, що й раніше. При цьому жодна з пацієнток протягом всієї вагітності не приймала глюкокортикостероїдів та гепарину.

ТАБЛИЦЯ 1. РЕФЕРЕНЦІЙНІ ПОКАЗНИКИ ТТГ, FТ4, FТЗ В ОКРЕМИХ ТРИМЕСТРАХ ВАГІТНОСТІ ПРИ СУПЛЕМЕНТАЦІЇ ЙОДУ $(\mathrm{n}=130)$

\begin{tabular}{|c|c|c|c|c|}
\hline Параметри & I триместр & II триместр & III триместр & Норми виробника \\
\hline ТТГ, мМ0/л & $0,01-2,32$ & $0,1-2,35$ & $0,1-2,65$ & $0,3-4,5$ \\
\hline fT4, мM0/л & $11,6-20,96$ & $10,64-18,12$ & $9,15-15,88$ & $11-22$ \\
\hline fТ3, мM0/л & $3,71-6,62$ & $3,52-5,89$ & $3,08-5,42$ & $3,1-6,8$ \\
\hline
\end{tabular}




\begin{tabular}{|l|l|}
\hline \multicolumn{1}{|c|}{ Перебіг } & \multicolumn{1}{c}{ Симптоми } \\
\hline Безсимптомний/субклінічний & $\begin{array}{l}\text { Відсутність об’єктивних/суб'єктивних симптомів } \\
\text { Результати біохімічних аналізів (рівень ТТГ) поза нормою }\end{array}$ \\
\hline Малосимптомний & \begin{tabular}{l} 
Нехарактерні симптоми: сонливість, схильність до закрепів, слабкість \\
\hline Явно виражений
\end{tabular} \\
\hline $\begin{array}{l}\text { Анемія; підвищений артеріальний тиск, індукований вагітністю; передчасне відшарування плаценти; } \\
\text { післяпологова кровотеча }\end{array}$ \\
\hline
\end{tabular}

\section{РЕЗУЛЬТАТИ ДОСЛІДЖЕННЯ}

\section{ТА ÏХ ОБГОВОРЕННЯ}

Пацієнтки з аутоімунним захворюванням ЩЗ (група А) мали вищий рівень ТТГ на початку вагітності і в перших двох триместрах (табл. 3). Рівень ТТГ безпосередньо перед пологами був вищий у групі В і становив 1,21 \pm 0,63 мМО/л. Рівень ТТГ у III триместрі вагітності був вищий у групі В $(1,78 \pm 3,2$ в порівнянні з 1,01 $\pm 0,62$ мМО/л в групі A), що може зумовлюватися прийомом пацієнтками групи А препаратів L-тироксину.

Показники ТТГ обох груп порівнювали протягом усього періоду вагітності. Із 282 вагітних субклінічну гіпофункцію ЩЗ виявлено у 11,7\% жінок ( $\mathrm{n}=$ 33). Серед 92 пацієнток із хронічним аутоімунним запаленням Щ3 у 24 (26,1\%) рівень ТТГ становив $>$ 2,5 мМО/л. У той же час у групі 190 жінок без ознак аутоімунного захворювання ЩЗ у $9(4,74 \%)(\mathrm{p}<0,02) 3$ них рівень ТТГ був > 2,5 мМО/л (табл. 4).

Захворювання ЩЗ у вагітних можуть призводити до порушень роботи ЩЗ плода і його неправильного розвитку. Це пов'язано з тим, що через плаценту транспортуються антипероксидазні (анти-ТПО), антитиреоглобулінові (антиТГ) антитіла та антитіла проти рецепторів ТТГ як стимулюючі, так і гальмуючі [27]. Підвище-
Разом із тим вплив гормонального дисбалансу Щ3 на розвиток плода є суттєвим. Між 10-м та 12-м тижнем вагітності щ3 під впливом ТТГ, що виділяється гіпофрізом плода, починається синтез йодтироніну [26]. Тому наявність гормонів ЩЗ необхідна для правильного розвитку плода вже на ранніх строках вагітності [1].

\begin{tabular}{|c|c|c|c|}
\hline & & & ТАБЛИЦЯ 3 \\
\hline Рівень ТTГ, мМО/л & Група A ( $\mathbf{n}=92)$ & Група B $(n=190)$ & p \\
\hline I триместр & $1,88 \pm 1,68$ & $1,57 \pm 0,84$ & $<0,05$ \\
\hline II триместр & $3,35 \pm 18,67$ & $1,54 \pm 0,77$ & $\begin{array}{l}\text { різниця не } \\
\text { достовірна }\end{array}$ \\
\hline III триместр & $1,01 \pm 0,62$ & $1,78 \pm 3,2$ & $<0,001$ \\
\hline Під час пологів & $0,95 \pm 0,60$ & $1,21 \pm 0,63$ & $<0,001$ \\
\hline
\end{tabular}

\section{У попередніх дослідженнях ми встановили,} що лише у $26,7 \%$ вагітних, які проживають у Кракові та його околицях, проведено рандомізовані дослідження функціонування щЗ [29]. Гіпофункція ЩЗ, яку не виявили або не пролікували, може призвести до ускладнення вагітності, що загрожуватиме передчасними пологами, небезпечними як для матері (кровотеча), так і для плода, а також порушенням розвитку пло-
ПЕРЕБІГ І СИМПТОМИ НЕДОСТАТНОСТІ ЩЗ У ВАГІТНИХ
ТАБЛИЦЯ 3. СЕРЕДНЯ КОНЦЕНТРАЦІЯ ТТГ У ВАГІТНИХ З АУТОІМУННИМ ЗАХВОРЮВАННЯМ ЩЗ

ТАБЛИЦЯ 4

Субклінічний гіпотиреоз

$\mathrm{TT} \Gamma>2,5 \mathrm{MMO} / \Omega$
Група A ( імунологічними захворюваннями Щ3), $\mathrm{n}=92$ n 24

$$
\%
$$

Усього: $11,7 \%(n=33)$ ний рівень анти-ТПО і/або анти-ТГ виявляється у $6-11 \%$ жінок із нормальною функцією щЗ, а також у 40-60\% пацієнток з ТТГ > 2,5 мМО/л [3, 13]. Досліджено, що частота викиднів у жінок 3 нормальною функцією щЗ за наявності антитиреоїдних антитіл становить 12-17\% і майже удвічі-утричі вища порівняно з популяцією вагітних, у яких відсутні анти-ТПО і/або анти-ТГ $[2,5,19]$. Однозначно не описано впливу антитиреоїдних антитіл на плід. Припускають, що їх проникнення через плаценту не призводить до незворотних порушень розвитку плода, проте може порушувати обмін гормонів щЗ $[6,8,22]$. да. У зв'язку з тим, що внаслідок фрізіологічних процесів під час вагітності змінюється обмін гормонів ЩЗ, необхідний адекватний тиреологічний контроль вагітних і тих, у кого виявлено захворювання щЗ до вагітності, і без цього захворювання в анамнезі.

\section{ВИСНОВОК}

Аутоімунні захворювання ЩЗ підвищують ризик появи субклінічної недостатності функціонування щЗ, особливо у вагітних. 


\section{ЛІТЕРАТУРА}

1. Abalovich M., Amino N., Barbour L.A. et al.

Management of thyroid dysfunction during pregnancy and postpartum: an Endocrine Society Clinical Practice Guideline. J. Clin. Endocrinol. Metab. 2007; 92 (8 Suppl.): S1-S47.

2. Banhadi N., Wiersinga W.M., Reitsma J.B., Vrijkotte T.G.M., Bonsel G.J.

Higher maternal TSH levels in pregnancy are associated with increased risk of miscarriage, fetal or neonatal death. Eur. J. Endocrinol. 2009; 160: 985-991.

3. Banhadi N., Wiersinga W.M., Reitsma J.B., Vrijkotte T.G.M., van der Wal M.F., Bonsel G.J.

Ethnic differences in TSH but not in free T4 concentrations or TP0 antibodies during pregnancy. Clin. Endocrinol. 2007; 66: 765-770.

4. Cotzias C., Wong S.J., Taylor E., Seed P., Girling J.

A study to establish gestation-specific reference intervals for thyroid function tests in normal singleton pregnancy. Eur. J. Obstet. Gynecol. Reprod. Biol. 2008; 137: 61-66.

5. De Vivi A., Mancuso A., Giaccobbe A. et al.

Thyroid function in women found to have early pregnancy loss. Thyroid 2010; 20: 633-637.

6. Hamm M.P., Cherry N.M., Martin J.W., Bamforth F.,

\section{Edmonton A.B.}

The impact of isolated maternal hypothyroxinemia on perinatal morbidity. J. Obstet. Gynaecol. Can. 2009; 31: 1015-1021.

7. Henrichs J., Bongers-Schokking J.J., Schenk J.J. et al. Maternal thyroid function during early pregnancy and cognitive functioning in early childhood: the generation R study. J. Clin. Endocrinol. Metab. 2010; 95: 4227-4234.

8. Iravatani A.T., Saeedi M.M., Pakravesh J., Hamidi S., Abbasi M. Thyroid autoimmunity and recurrent spontaneous abortion in Iran: a case-control study. Endocr. Pract. 2008; 14: 458-464.

\section{Karbownik-Lewińska M.}

Thyroid dysfunction during pregnancy. Invited Lecture. 11th European Congress of Endocrinology 25-29.04.2009 r., Istanbul, Turcja, Endocr. Abstr. 2009; 20, S26.2.

10. Karbownik-Lewińska M., Zygmunt A.

Choroby endokrynologiczne u kobiet w ciąży i w okresie fizjologicznej laktacji. In: Lewiński A, Zygmunt A (eds). Diagnostyka czynnościowa zaburzeń hormonalnych z elementami diagnostyki rożnicowej. Czelej, Lublin 2011: 241-250.

11. Koutras D.A.

Thyroidopaties. Ann. N.Y. Acad. Sci., 2000, 900, $77-88$.

12. Krysiak R., Okopień B., Herman Z.S.

Nadczynność tarczycy w ciąży. Pol. Merk. Lek., 2006, XXI, 126, 579.

13. Lambert-Messarlian G., Mcclain M., Haddow J.E. et al. and the FaSTER Consortium.

First and second trimester thyroid hormone reference data in pregnant women: a FaSTER (First and Second Trimester Evaluation of Risk for aneuploidy) Research Consortium study. Am. J. Obstet. Gynecol. 2008; 1999: 62e.1-62e6.

14. La'Ulu S.L., Roberts W.L.

Second-trimester reference intervals for thyroid tests: the role of ethnicity. Clinical Chemistry 2007; 53: 1658-1664.
15. Li Y., Shan Z., Teng W. et al.

Abnormalities of maternal thyroid function during pregnancy affect neuropsychological development of their children at 25-30 months. Clin. Endocrinol. 2010; 72: 825-829.

16. Malkawi O.M.

Thyroid disease and pregnancy. Saudi Med. J. 2002, 23, 633-639.

17. Mannisto T., Vaarasmaki M., Pouta A. et al.

Perinatal outcome of children born to mothers with thyroid dysfunction or antibodies: a prospective population-based cohort study. J. Clin. Endocrinol. Metab. 2009; 94: 772-779.

18. Nunez J.

Effects of thyroid hormones during brain differentiation. Mol. Cell. Endocrinol. 1984. 37: 125-132.

19. Oken E., Braverman L.E., Platek D., Mitchell M.L., Lee S.L., Pearce E.N.

Neonatal thyroxine, maternal function and child cognition. J. Clin. Endocrinol. Metab. 2009; 94: 497-503.

20. Sahu M.T., Das V., Mittal S., Agarwal A., Sahu M.

Overt and subclinical thyroid dysfunction among Indian pregnant women and its effect on maternal and fetal outcome. Arch Gynecol. Obstet. 2010; 81: 215-220.

21. Patel J., Landers K., Li H., Mortimer R.H., Richard K. J.

Endocrinol. Thyroid hormones and fetal neurological development. 2011 Apr; 209 (1):

1-8. Epub. 2011, Jan 6.

22. Patel J., Landers K., Li H., Mortimer R.H., Richard K.

Delivery of maternal thyroid hormones to the fetus. Trends Endocrinol. Metab. 2011, Mar 15.

23. Porterfield S.P., Hendrich, C.E.

The role of thyroid hormones in prenatal and neonatal neurological development current perspectives. Endocr. Rev. 1993. 14: 94-106.

\section{Schwartz H.L.}

Effect of thyroid hormone on growth and development. In: Molecular basis of thyroid hormone action (Oppenheimer, JH, Samuels, HH), New York: Academic Press. 1983, pp. 413-444.

25. Springer D., Zima T., Limanova Z.

Reference intervals in evaluation of maternal thyroid function during the first trimester of pregnancy. Eur. J. Endocrinol. 2009; 160: 791-797.

26. Stricker R., Echenard M., Eberhard R. et al.

Evaluation of maternal thyroid function during

pregnancy: the importance of using gestational age-specific reference intervals. Eur. J. Endocrinol. 2007; 157: 509-514.

27. Wasserman E.E., Nelson K., Rose N.R. et al.

Maternal thyroid autoantibodies during the third trimester and hearing deficits in children: an epidemiologic assessment. Am. J. Epidemiol. 2008; 167: 701-710.

28. Hubalewska-Dydejczyk A. i wsp.

Postępowanie w chorobach tarczycye u kobiet w ciąży. Endokrynologia Polska, Tom 63, Nr 4. 2011, str. 362-380

29. Tomasz Milewicz, Małgorzata Żuk, Ewa Stochmal i wsp.

Wiek, miejsce zamieszkania i wykształcenie wpływają na zgłaszalność ciężarnych do badań przesiewowych funkcji tarczycy - badanie ankietowe. Endokrynol. Pol. 2011; 62 (5): 416-420.

\section{www.reproduct-endo.com.na}
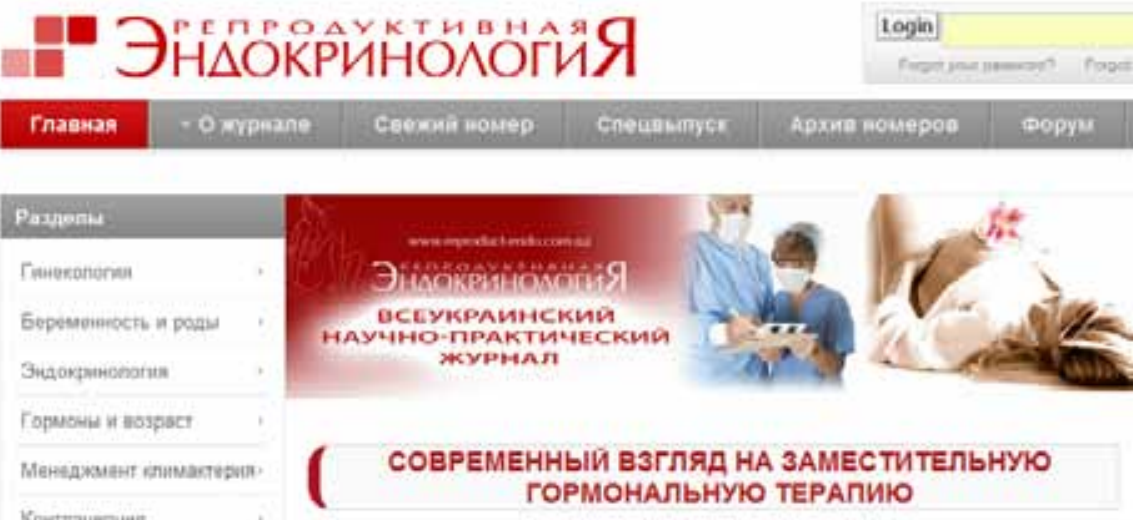

СОВРЕМЕННЫИ ВЗГЛЯД НА ЗАМЕСТИТЕЛЬНУО ГОРМОНАЛЬНУЮ ТЕРАПИЮ 